\title{
THE FLAT CLAM CONTROVERSY: WHERE DID THEY COME FROM? WHERE DID THEY GO?
}

KAUFFMAN, Erle G., VILLAMIL Tomás, HARRIES, Peter J., MEYER, Christian A., Department of Geological Sciences, CB-250 University of Colorado, Boulder, CO 80309-0250, USA; SAGEMAN, Bradley, B., Department of Geosciences, Pennsylvania State University, University Park, PA 16802

Thin-shelled, weakly articulated, epifaunal byssate to free-living flat clams characterize Devonian-Cretaceous dark, organic-rich shale facies. Convergent evolution on the flat-clam morph occurs among several families of Bivalvia. Flat clams regularly occurred in dense populations, dominating low diversity, inequitable communities for which they were commonly the pioneer species and formed shell islands for the colonization of smaller, firm-substrate dependent invertebrates. The unique flat-clam dominated ecosystem, as well as the widespread environments to which they were adapted, disappeared at the end of the Cretaceous. Although locally, low-oxygen benthic muds exist through the Cenozoic to Recent, they do not support large populations of flat clams, whose ecological niche was never filled after the Cretaceous. Flat clams underwent an exponential increase in size and apparent growth rates through the mid- and Late Cretaceous, reaching over $3 \mathrm{~m}$ in diameter (Inoceramidae). Most of this increase in shell size also involved expansion of mantle tissue and probably gills, relative to the size of the visceral mass. This suggests specific adaptations to colonization of oxygen-poor benthic habitats with hydrogensulfide enriched substrates, which broadly characterized Paleozoic and Mesozoic epicontinental seas, during greenhouse intervals. Such conditions were particularly well-developed during Cretaceous Oceanic Anoxic Events, at which time flat clams thrived.

Functional morphology, geochemistry, and facies associations suggest that many flat clams were chemosymbiotic and/or had greatly expanded oxygen-absorption surfaces. These adaptations allowed them to be opportunistic in chemically stressed benthic environments; growth rates also seem to be enhanced in these environments, a characteristic of living chemosymbiotic species. Many lines of evidence prove that flat clams lived in these environments and do not represent pseudoplanktic rain. A combination of factors seems to have been responsible for their disappearance near the end of the Cretaceous; i.e., mass extinction, loss of primary habitats, and major radiation among bottom-feeding bivalve predators. 